\title{
Role of Dominant Follicle Count in Controlled Ovarian Stimulation with Intrauterine Insemination Cycles in Patients with Unexplained Infertility
}

Açıklanamayan İnfertiliteli Hastalarda Kontrollü Overyan Hiperstimulasyon ve İntrauterin İnseminasyon Sikluslarında Dominant Folikül Sayısının Rolü

Gürkan YAZICI, Hüseyin DURUKAN, Aysun SAVAŞ

Mersin Üniversitesi Tıp Fakültesi, Kadın Hastalıkları ve Doğum Anabilim Dalı

\section{ABSTRACT}

Objective: The aim of the present study was to determine the predictive value of dominant follicle count as a marker for pregnancy and multiple pregnancy rate in controlled ovarian hyperstimulation $(\mathrm{COH})$ with intrauterine insemination (IUI) cycles in couples with unexplained subfertility.

Material and Methods: The study was designed as a prospective non-randomized trial and involving 214 women with unexplained infertility was underwent $\mathrm{COH}-\mathrm{IUI}$ at a University of Mersin School of Medicine, Obstetric and Gynecology department between May 2008 and September 2010.

Results: Of $532 \mathrm{COH}$ cycles started, 513 were completed and resulted in 62 clinical pregnancies (12.1\% per completed cycle). There were $9(14.5 \%)$ multiple pregnancies and $7(11.3 \%)$ miscarriages. In cycles with a single, two and three dominant follicles $(>16 \mathrm{~mm})$ on the day of hCG the clinical pregnancy rate were $8.3 \%, 14.7 \%$ and $27.1 \%$ respectively. Three dominant follicles $(>16 \mathrm{~mm})$ count have increased pregnancy rate more than the 1 or 2 ( $p$ value 0.001 and 0.044 respectively). In addition cycles with a single, two and three dominant follicles the multiple pregnancy rate were $7.4 \%, 15.8 \%$ and $25 \%$ respectively. The multiple pregnancy rate was similar in cycles with 1 and 2 dominant follicles and lower than three (p:0.004).

Conclusion: Three follicular growths are associated with increased pregnancy rates in $\mathrm{COH}$-IUI women with unexplained subfertility. In cycles with one or two follicles, the multiple pregnancy rates are not significantly different however 3 dominant follicles associated with increased multiple pregnancy rates.

Keywords: insemination, ovarian follicle, ovulation induction, infertility

İletişim Bilgileri:

Sorumlu Yazar: Hüseyin Durukan

Yazışma Adresi: Mersin Üniversitesi Tıp Fakültesi,

Kadın Hast. ve Doğum Anabilim Dalı, Mersin, Turkey

Tel: +90 5053745857

E-mail: huseyindurukan@gmail.com

Makalenin Geliş Tarihi: 21.07.2014

Makalenin Kabul Tarihi: 04.08.2014

\section{ÖZET}

Amaç: Bu çalışmanın amacı açıklanmayan infertilite nedeniyle kontrollü overyan hiperstimülasyon $(\mathrm{KOH})$ ve intrauterin inseminasyon (IUI) yapılan kadınlarda dominant folikül sayısının gebelik başarısı ve çoğul gebelik oranları üzerine etkilerini değerlendirmektir.

Gereç ve Yöntemler: Prospektif ve non-randomize olarak planlanan ve Mersin Üniversitesi Kadın Hastalıkları ve Doğum Ana Bilim Dalı'nda yapılan bu çaIışmaya Mayıs 2008 ile Eylül 2010 tarihleri arasında açıklanamayan infertilite tanısı ile $\mathrm{KOH}-\mathrm{IUI}$ uygulanan 214 kadın dahil edildi.

Bulgular: $\mathrm{KOH}$ başlanan 532 siklustan 513'ü tamamlanarak IUI yapılmış ve 62 klinik gebelik elde edilmiştir (siklus başına klinik gebelik oranı \%12,1). Bu gebeliklerden 9'unda çoğul gebelik $(\% 14,5)$ gelişirken 7'si $(\% 11,3)$ ise abortusla sonuçlanmıştır. hCG günü tek, iki ve üç dominant folikül (>16 mm) gelişen sikluslardaki klinik gebelik oranları sırasıyla $\% 8,3, \% 14,7$ ve $\% 27,1$ olarak saptanmıştır. Klinik gebelik oranı bir ve iki dominant folikül gelişen olgularda benzerken ( $p>0,05)$, üç dominant folikül gelişen olgularda bir ve iki dominant folikül gelişenlere kıyasla daha yüksek bulunmuştur ( $p$ değerleri sırası ile 0,001 ve 0,044). Bir, iki ve üç folikül gelişen olguların çoğul gebelik oranları ise sırasıyla $\% 7,4$, \%15,8 ve \%25 olarak saptanmıştır. Çoğul gebelik oranları bir ve iki dominant folikül gelişen olgularda benzerken ( $p>0,05)$, üç dominant folikül gelişen olgularda bir ve iki dominant folikül gelişenlere kıyasla istatistiksel anlamlı olarak daha yüksek bulunmuştur $(p=0,004)$.

Sonuç: Açıklanamayan infertilite nedeniyle $\mathrm{KOH}-\mathrm{I}-$ UI yapılan kadınlarda hCG günü üç folikül gelişimi artmış gebelik oranı ile ilişkilidir. Ancak, üç folikül gelişimi artmış çoğul gebelik oranına da sahiptir.

Anahtar Kelimeler: İnfertilite, inseminasyon, overyan folikül, ovülasyon indüksiyonu. 


\section{INTRODUCTION}

Intrauterine insemination (IUI) is the therapeutic process after semen preparation and concentration of motile spermatozoa in a small volume of culture medium (1). IUI is a preferred method in the treatment of subfertile couples with various causes of subfertility, including cervical factor, male factor and unexplained infertility (2). Controlled ovarian hyperstimulation $(\mathrm{COH})$ with IUI was shown to result in significantly higher pregnancy rates (PR) per woman as compared with IUI in the natural cycle on couples with unexplained subfertility (odds ratio [OR]: 2.3, 95\% confidence interval [CI]: 1.5-3.7) (3). COH-IUI is a simpler, less invasive and cheaper first-line treatment than in-vitro fertilization (IVF) for subfertility, resulting in a acceptable PR $10-20 \%$ per cycle (2). Several factors that may influence of COH-IUI outcome, including infertility etiology, woman age, infertility duration, sperm parameters, the use of ovulation induction agents, techniques used for sperm preparation, timing and number of inseminations, thickness of endometrium, total antral follicle count, and number of dominant follicles on the day of human chorionic gonadotropin (hCG) (1, 4-6). However, the effect of dominant follicles counts on the day of hCG is controversial in current literature (4-6). The aim of the present study was to determine the predictive value of dominant follicle count as a marker for pregnancy and multiple pregnancy rates in $\mathrm{COH}-\mathrm{IUI}$ cycles in couples with unexplained subfertility.

\section{MATERIAL AND METHOD}

The design of the study was approved by the local ethics committee (B.30.2. MEU.0.20.05.04/143) and each patient gave written informed consent.

\section{Subjects}

A prospective trial involving 214 couples with unexplained infertility was underwent COH-IUI at a single university hospital between May 2008 and September 2010. All couples underwent standard infertility investigation consisting of anamnesis, physical examination, assay of prolactin, thyroid hormone, serum follicle-stimulating hormone (FSH) concentrations on cycle day 3 and mid-luteal progesterone concentration on cycle day 21 , assessment of tubal patency, and semen analysis. Patients were included in the study if they fulfilled the following criteria: (i) history of primary infertility of $>2$ years, (ii) woman's age between 20 and 40 years, (iii) documentation of normal ovula- tory cycles, (iv) patent tubes have been shown by hysterosalpingography (HSG) or laparoscopy $(\mathrm{L} / \mathrm{S})$ and $(\mathrm{v})$ normal sperm parameters. Exclusion criteria are as follows: (i) previous assisted reproduction technology (ART) cycle, (ii) previous $\mathrm{COH}-\mathrm{IUI}$ cycle and (iii) history of pelvic surgery.

\section{Hormonal measurements}

FSH, progesterone, and estradiol (E2) levels were assayed with the electrochemoluminescent immunoassay method using Roche Elecsys 2010 automated immunoassay analyser (Roche Diagnostics GmbH; Mannheim, Germany).

\section{Transvaginal ultrasonography}

Transvaginal ultrasonography was performed by using a Logic 500 (General Electric; Milwaukee, USA) with a 5-MHz vaginal transducer by the same physician (AS). All ovarian follicles measuring $5 \mathrm{~mm}$ to $10 \mathrm{~mm}$ on both ovaries were counted on cycle day 3 . The total number was expressed as the antral follicle count (AFC). Ovarian follicles measuring $\geq 10$ $\mathrm{mm}$ in diameter were accepted as dominant follicles. The total numbers were used for calculations

\section{Controlled ovarian hyperstimulation and monitoring}

Patients received $75 \mathrm{IU} /$ day s.c. recombinant FSH (Puregon $\AA$, Schering-Plough, US) from cycle day 3 until follicular maturation was reached. If follicular development (one follicle $>10 \mathrm{~mm}$ ) was not seen on day 10 , the dose was increased to $112.5 \mathrm{IU} /$ day. The follicular growth and endometrial thickness was monitored by transvaginal ultrasonography. When at least one follicle with a diameter of 17 or 18 $\mathrm{mm}$ was presented, final oocyte maturation was induced by the administration of 10.000 IU hCG (Pregnyl ${ }^{\circledR}$, Schering-Plough, US). Patients were divided in three groups according to the number of dominant follicle counts: Group 1: one follicle, Group 2: two follicles, Group 3: three follicles. HCG administration and IUI were withhold when monitoring revealed the growth of more than three follicles with a diameter of $16 \mathrm{~mm}$, or more than five follicles with a diameter of $12 \mathrm{~mm}$.

\section{Semen analysis and sperm preparation}

All semen samples were collected by masturbation into sterile containers at the clinical andrology laboratory after a period of 3-5 days of sexual abstinence. Native semen was left in $37{ }^{\circ} \mathrm{C}$ temperature for liquefaction in $30-60 \mathrm{mi}-$ nutes. Prior to preparation, initial sperm analy- 
sis was performed according to World Health Organization guidelines and total motile sperm counts (TMSC; ejaculate volume $\mathrm{x}$ concentration $\mathrm{x}$ motile fraction) were calculated on all semen analyses (7). Semen samples were prepared by density gradient centrifugation (DGS) methods using ISolate ${ }^{\circledR}$ (IrvineScientific; Santa Ana, CA, USA) mediums. ISolate ${ }^{\circledR}$ is a membrane filtered, aseptically processed colloidal suspension of silica particles stabilized with covalently bound hydrophilic saline in HEPES-buffered human tubal fluid (HTF). Media were brought in $37^{\circ} \mathrm{C}$ temperature. Using a sterile pipette $2.0 \mathrm{~mL}$ of the 'Upper Layer solution' (50\% gradient) was transferred into a $15 \mathrm{ml}$ conical Falcon tube. Using a new sterile pipette $2.0 \mathrm{~mL}$ of the 'Lower Layer solution' (90\% gradient) was gently dispensed under the lower layer solution. Lastly, $2.0 \mathrm{~mL}$ of liquefied semen sample was then placed on top of the upper layer and tube was centrifuged for $20 \mathrm{mi}-$ nutes at $350 \mathrm{~g}$. The upper and lower layers were carefully aspirated without disturbing the pellet. Using a new transfer pipette, $2 \mathrm{~mL}$ of sperm washing medium (modified HTF) was added and the re-suspended pellet was centrifuged for 10 minutes at $300 \mathrm{~g}$. The supernatant was then removed and the pellet suspended in a volume of $0.5 \mathrm{~mL}$ modified HTF. All procedures were conducted under sterile conditions.

\section{Intrauterine insemination}

A single insemination per cycle was performed $36 \mathrm{~h}$ post-HCG administration. The procedure was carried out using an IUI catheter (C.C.D. Laboratoire; Paris, France) with a 1 $\mathrm{mL}$ syringe. With the woman in the lithotomy position, the IUI catheter was gently directed into the uterine lumen and the $0.5 \mathrm{~mL}$ prepared sperm suspension slowly infused. The women were allowed to stand up 15 minutes after procedure. Serum $\beta$-hCG levels were measured 14 days after IUI. Clinical pregnancy was defined as identification of a gestational sac 2-3 weeks after IUI. Early miscarriage was defined as pregnancy ending before 12 weeks of gestation.

\section{Statistical analysis}

Independent sample $t$ test was used to compare pregnant and nonpregnant groups. Association between pregnancy rate and dominant follicle count was examined with chi-square test. Two proportion comparison method was used to detect group showing significantly different rate. Odds ratio was calculated for significantly different group. SPSS v.11.5.1 and MedCalc v.11.0.0 packages were used for statistical analysis. $\mathrm{P}$ values below 0.05 were accepted statistically significant. Descriptive statistics of continues variables were presented as mean \pm standard deviation and of categorical variables were presented frequencies and percentiles.

\section{Results}

Data was obtained from the 214 couples with unexplained infertility were underwent COH-IUI. The women's mean age was 30.14 \pm 5.27 years (range 20-39). There were no differences in age, Body mass index, duration of infertility, total antral follicle number, basal serum FSH and mid-luteal progesterone concentration, and total motile sperm count in pregnant and non-pregnant groups. The baseline and demographic characteristics of couples are shown in Table I.

Table I. Comparison of baseline characteristics between the pregnant and nonpregnant groups.

\begin{tabular}{|l|c|c|c|}
\hline & Nonpregnant group & Pregnant group & $p$ value \\
\hline & $(\mathrm{n}=152)$ & $(\mathrm{n}=62)$ & 0.542 \\
\hline Female's age (yr) & $30.28 \pm 5.30$ & $29.79 \pm 5.21$ & 0.843 \\
\hline Body mass Index $\left(\mathrm{kg} / \mathrm{m}^{2}\right)$ & $23.96 \pm 2.68$ & $23.88 \pm 2.82$ & 0.625 \\
\hline Infertility duration (month) & $64.19 \pm 45.41$ & $60.90 \pm 42.46$ & 0.817 \\
\hline Total antral follicle number & $6.99 \pm 1.88$ & $6.92 \pm 2.05$ & 0.984 \\
\hline Basal serum FSH concentration (mIU/L) & $5.80 \pm 1.78$ & $5.81 \pm 1.88$ & 0.163 \\
\hline Basal serum progesterone concentration $(\mathrm{ng} / \mathrm{mL})$ & $7.53 \pm 5.03$ & $8.60 \pm 5.18$ & 0.654 \\
\hline Male's age (yr) & $30.30 \pm 6.07$ & $29.92 \pm 5.05$ & 0.920 \\
\hline Total motile sperm count $\left(10^{6}\right)$ & $76.53 \pm 68.63$ & $77.54 \pm 61.61$ & $0.153-$ \\
\hline
\end{tabular}


Table II. Cycle characteristics in the groups.

\begin{tabular}{|l|c|c|c|}
\hline \multirow{2}{*}{} & Nonpregnant & Pregnant & \multirow{2}{*}{ p value } \\
\cline { 2 - 3 } & group $(\mathrm{n}=451)$ & group $(\mathrm{n}=62)$ & \\
\hline Duration of stimulation (day) & $9.24 \pm 2.63$ & $9.09 \pm 2.62$ & 0.134 \\
\hline Total gonadotropin dose per cycle $(\mathrm{IU})$ & $912.20 \pm 396.20$ & $908.27 \pm 435.99$ & 0.942 \\
\hline Serum E2 concentration on the day of hCG $(\mathrm{pg} / \mathrm{mL})$ & $502.56 \pm 259.37$ & $605.25 \pm 330.49$ & 0.005 \\
\hline No. of dominant follicles $(>16 \mathrm{~mm})$ on the day of hCG & $1.43 \pm 0.66$ & $1.82 \pm 0.82$ & 0.001 \\
\hline
\end{tabular}

Table III. Clinical pregnancy rates per cycle and the frequency of multiple pregnancies for the groups classified according to the number of follicles $>16 \mathrm{~mm}$ on day of hCG.

\begin{tabular}{|l|c|c|c|c|}
\hline & Group 1 & Group 2 & Group 3 & p value $^{*}$ \\
\hline Clinical pregnancy rate \% $(\mathrm{n})$ & $8.3(27)$ & $14.7(19)$ & $27.1(16)$ & 0.001 \\
\hline Multiple pregnancies/clinical pregnancies \% (n) & $7.4(2)$ & $15.8(3)$ & $25.0(4)$ & 0.004 \\
\hline
\end{tabular}

${ }^{*} \mathrm{P}$ value represent significance of group 3 compared to both group 1 and group 2 .

Of 532 IUI cycles started, 513 were completed and resulted in 62 pregnancies $(12.1 \%$ per completed cycle). There were 9 (14.5\%) multiple pregnancies and $7(11.3 \%)$ miscarriages. The majority of the 19 cancelled cycles were the result of mild/moderate ovarian hyperstimulation syndrome (OHSS) with excess follicular growth. With regard to the ovarian cycle parameters, there was no significant difference in pregnant and non-pregnant groups, but mean serum E2 concentration and number of dominant follicles $(>16 \mathrm{~mm})$ on the day of hCG was significantly higher in the pregnant cycles as compared with nonpregnant cycles (Table II). In cycles with a single and two dominant follicles $(>16 \mathrm{~mm})$ on the day of hCG the clinical PR were $8.3 \%$ and $14.7 \%$ respectively and the clinical PR was not significantly different in patients with group 1 and group $2(p=0.062)$. However, clinical PR was increased in group 3 compared to the group 1 or group 2 ( $\mathrm{p}$ value 0.001 and 0.044 respectively). The highest PR $(27.1 \%)$ in this regard was observed with 3 dominant follicles $(>16 \mathrm{~mm})$ on the day of hCG; OR: $3.30,95 \%$ CI: $1.73-6.32, p=0.001$. The multiple PR was significantly different among groups (Table III).

\section{DISCUSSION}

IUI is a common treatment in couples with unexplained subfertility. IUI can be performed with or without $\mathrm{COH}$. Several studies, performed in $\mathrm{COH}$ combination with IUI, have been shown to result in significantly higher cumulative PR per couple as compared with unstimulated IUI, $\mathrm{COH}$ alone or IUI alone in couples with unexplained subfertility $(3,8)$. The major benefit of introducing COH-IUI is considered to be due to the induction of multifollicular growth. However, the serious drawback of excess follicles stimulation in COH-IUI is a risk for multiple pregnancies and OHSS (9). Most of studies have been performed to search for these differences in PR, and for determinants of success concerning COH-IUI therapy. It has been demonstrated that an increasing female age, a longer duration of infertility and a poor sperm quality have a negative impact on the PR in couples receiving COH-IUI $(2,9)$. However, studies reporting that the number of dominant follicles on the day of hCG in relation to pregnancy and multiple pregnancy rate in COH-IUI cycles with unexplained subfertile couples, have demonstrated contradictory results. Some studies have shown multifollicular growth did not improve the PR significantly on couples with unexplained subfertility $(6,9,10)$. Van Rumste et al. (9) reported couples with unexplained non-conception that had one follicle at the time of HCG administration had an ongoing PR of $7.9 \%$, and couples who had multifollicular growth had an ongoing PR of $8.5 \%$. The difference in PR found between these two groups was not statistically significant (OR: $1.1,95 \%$ CI: 0.6-2.0). Similarly, Erdem et al. (6) determined that the number of dominant follicles on the day of hCG is not associated with PR (OR: 0.81, 95\% CI: 0.44-1.49). In contrast to these observations, Ibérico et al. (11) showed an increase in PR when follicle number rises on couples with unexplained subfertility. They reported that IUI with three follicles almost tripled the PR with respect to only one; OR: $2.89,95 \%$ CI: $1.54-$ 5.41.van Rumste et al. (12) analysed 14 studies that performed $\mathrm{COH}-\mathrm{IUI}$ on couples with various factor of infertility. They concluded that the pooled OR for PR after two and three follicles as compared with monofollicular growth was 1.6 and 2.0 (99\% CI: $1.3-1.9$ and $99 \% \mathrm{CI}$ : 1.6-2.5). Also in our study, having three follicles on the day of hCG increased PR more than monofollicular and two follicular growth ( $p$ value 0.001 and 0.044 respectively). The highest PR $(27.1 \%)$ in this regard was observed with 3 dominant follicles (>16 mm); OR: 3.30, 95\% 
CI: 1.73-6.32, $\mathrm{p}=0.001$. However, the incidence of multiple PR after COH-IUI is unclear, it is estimated that is $10-40 \%$ per cycle, and that 30 $50 \%$ are due to COH-IUI (13). In the literature, there is controversy concerning the number of dominant follicles in $\mathrm{COH}-\mathrm{IUI}$ and subsequent multiple PR. van Rumste et al. (12) showed that of the 1481 pregnancies found in the 12 studies, there were 274 multiple pregnancies $(18.5 \%)$. The pooled OR for multiple pregnancies per conceived cycle after two follicles as compared with monofollicular growth was 1.7 (99\% CI: 0.8-3.6). In addition three or four follicles increased the multiple PR more than monofollicular growth (OR: 2.8 and 2.3, respectively). In support to this observation we found there was no significant difference in multiple PR between one or two follicular growth $(p=0.676)$. But also 3 dominant follicles were associated with increased multiple PR, compared with monofollicular growth $(p=0.001)$.

In conclusion, three follicular growths are associated with increased pregnancy rates in $\mathrm{COH}-\mathrm{IUI}$ with unexplained subfertility. In cycles with one or two follicles, the multiple pregnancy rates are not significantly different however 3 dominant follicles are associated with increased multiple pregnancy rate.

\section{REFERENCES}

1. Abdelkader AM, Yeh J. The potential use of intrauterine insemination as a basic option for infertility: a review for technology-limited medical settings. Obstet Gynecol Int 2009;2009:584837.

2. Duran HE, Morshedi M, Kruger T, Oehninger S. Intrauterine insemination: a systemic review on determinants of success. Hum Reprod 2002;8:373-84.

3. Verhulst SM, Cohlen BJ, Hughes E, Te Velde E, Heineman MJ. Intra-uterine insemination for unexplained subfertility. Cochrane Database Syst Rev 2006;18:CD001838.

4. Nuojua-Huttunen S, Tomas C, Bloigu R, Tuomivaara $L$, Martikaninen $H$. Intrauterine insemination treatment in subfertility: an analysis of factors affecting outcome. Hum Reprod 1999;14:698-703.
5. Guven S, Gunalp GS, Tekin Y. Factors influencing pregnancy rates in intrauterine insemination cycles. J Reprod Med 2008;53:257-65.

6. Erdem M, Erdem A, Guler I, Atmaca S. Role of antral follicle count in controlled ovarian hyperstimulation and intrauterine insemination cycles in patients with unexplained subfertility. Fertil Steril 2008;90:360-6.

7. World Health Organization. WHO laboratory manual for the examination of human semen and sperm-cervical mucous interaction, 4th ed. Cambridge: Cambridge University Press; 1999.

8. Guzick DS, Carson SA, Coutifaris C, Overstreet JW, Factor-Litvak P, Steinkampf MP, et al. Efficacy of superovulation and intrauterine insemination in the treatment of infertility. National Cooperative Reproductive Medicine Network. New Engl J Med 1999;340:177-83.

9. van Rumste MM, den Hartog JE, Dumoulin JC, Evers JL, Land JA. Is controlled ovarian stimulation in intrauterine insemination an acceptable therapy in couples with unexplained non-conception in the perspective of multiple pregnancies? Hum Reprod 2006;21:701-4.

10. Steures P, van der Steeg JW, Hompes PG, Habbema JD, Eijkemans MJ, Broekmans FJ, et al. Intrauterine insemination with controlled ovarian hyperstimulation versus expectant management for couples with unexplained subfertility and an intermediate prognosis: a randomised clinical trial. Lancet 2006;368:216-21.

11. Ibérico G, Vioque J, Ariza N, Lozano JM, Roca M, Llácer J, Bernabeu R. Analysis of factors influencing pregnancy rates in homologous intrauterine insemination. Fertil Steril 2004;81:1308-13.

12. van Rumste MM, Custers IM, van der Veen $F$, van Wely M, Evers JL, Mol BW. The influence of the number of follicles on pregnancy rates in intrauterine insemination with ovarian stimulation: a meta-analysis. Hum Reprod 2008;14:563-70.

13. Fauser BC, Devroey P, Macklon NS. Multiple birth resulting from ovarian stimulation for subfertility treatment. Lancet 2005;365:1807-16. 